\title{
Determining The Effect of Diurnal Variability on Some Yield and Quality Characteristics of Saffron (Crocus sativus L.)
}

\author{
Kaan Erden (Corresponding author) \\ Agricultural Faculty, Department of Field Crops, Harran University, \\ PO box 63150, Sanliurfa, Turkey \\ E-mail: erdenk@harran.edu.tr \\ Abdulhabip Ozel \\ Agricultural Faculty, Department of Field Crops, Harran University, \\ PO box 63150, Sanliurfa, Turkey \\ E-mail: hozel@harran.edu.tr
}

\begin{abstract}
This study was conducted to determine the effect of diurnal variability on yield and quality characteristics of saffron (Crocus sativus L.) under the conditions of Harran Plain on research fields of Faculty of Agriculture of Harran University during winter growing seasons in 2006-2007 and 2007-2008. The trial was arranged in randomized complete block design with three replicates. For determining the effect of diurnal variability, three different flower harvest times were used in the research: 07.00 hours, 12.00 hours and 17.00 hours. The following parameters including plant heights $(50.47-50.73 \mathrm{~cm})$, stigma lengths $(3.44-3.47 \mathrm{~cm})$, stigma weights $(7.55-7.57 \mathrm{mg})$, saffron yields $\left(1958.7-1959.5 \mathrm{~g} \mathrm{da}^{-1}\right)$, safranal ratio (\% 37.57-39.93), crocin ratio (\%o192.5-200.0), picrocrocin ratio (\% $\% 6.97-89.63)$, corm numbers per plant $\left(4.77-4.87\right.$ number plant $\left.{ }^{-1}\right)$, corm yields $\left(3663.0-3669.0 \mathrm{~kg} \mathrm{da}^{-1}\right)$ and marketable corm ratios (\%70.90-71.67) were determined in the study. As a result, it was recommended that the saffron should be harvested at 07:00 and at the day of full flowering under Harran Plain conditions.
\end{abstract}

Keywords: Saffron, Crocus sativus, Diurnal variability, Crocin, Safranal, Picrocrocin

DOI: $10.7176 / \mathrm{JSTR} / 6-01-06$

\section{Introduction}

Saffron (Crocus sativus L.) is a plant known since ancient times and used as a spice and sweetener in food and beverage industry and also in medicine, cosmetic and dye industries due to its fragrance, color and taste. Homer and Hippocrates, ancient Greek, Roman and Egyptian Civilizations reported the common use of saffron in dyeing, perfume, medicine and as spice in foods-beverages (Gümüşsuyu 2003). In addition, it is used in the mixtures of products in food industry including cakes, cookies, biscuits, confectionery, delight, soup, chicken, baked bakery products, sauces, desserts, cheese and butter, and people regard it as an indispensable component of rice, soup and meat dishes and some traditional deserts like Zerde (Leung 1980; Douglas \& Mc Gimpsey 1993; Koç 2002).

In traditional and modern medicine and pharmaceutics, it is used as stimulant, appetizing, aphrodisiac, for strengthening heart muscles, sedative, dysentery preventive, therapeutic, expectorant, crisis and painrelieving, freckles and acne remover, constipation agent, stomach strengthening, for the complaints of gout, bronchitis and cough, anti-depressant, anti-spasmodic, for the treatment of gynecological diseases and anti-tumor effects. Furthermore, it is included in the composition of medicines used against fever, measles and splenomegaly (Baytop 1984; Şekercioğlu 1999; Demirhan 2002; Koç 2002). Saffron, Crocus sativus L. has desiccated stigmata and contains fixed oil (5.9\%), volatile oil (0.4-1.3\%), protein (11\%), water (11.9\%), carbohydrate (64.4\%), fiber (3.9\%), ash (5.4\%) (111 mg Ca, $11 \mathrm{mg} \mathrm{Fe,} 252 \mathrm{mg} \mathrm{P,}$ $1724 \mathrm{mg} \mathrm{K}, 148 \mathrm{mg} \mathrm{Na}$ ) and B2 vitamin (Riboflavin). The most important component of volatile oil is the aldehyde known as safranal (turpenic) (47\%), which gives saffron its distinctive spice scent. The bitterness of saffron derives from colorless picrocrocin (4\%). The peculiar color of saffron results from crocin (\%24-27). Crocin is a bright yellow component and allows saffron to paint 100.000-150.000 times more than its own weight (Koç 2002). The amount of this agent which enables saffron to be used as spice

$60 \mid \mathrm{P}$ a g e

www.iiste.org 
and medical plant is the most important component for the quality of saffron (Gresta et al. 2009). The amount of this agent also determines the price of saffron in international trade. An economic saffron production is only possible with a good quality of production. Different ecotypes of Crocus sativus L. plant are used in saffron producer countries and there are partial quality differences among these ecotypes. However, the main factor determining the active ingredient is the climate characteristics of the saffron cultivation location (Gresta et al. 2009; Zougagh et al. 2006). Researchers have stated that some factors including temperature, relative humidity, day length, light intensity etc. have important effects on quality, and the studies conducted on different saffron cultivation locations have revealed different analysis results considering saffron components (Çavuşoğlu \& Erkel 2005; Özel \& Erden 2005; Özel \& Erden 2008; Ipek et al. 2009; Molina et al. 2005). Gresta et al. (2009) and Zougagh et al. (2006) reported that saffron cultivation location has important effects on the quality and this is caused by climate factors of the location and also the environmental factors during harvest time are effective on saffron quality. This situation reveals that climate factors to which saffron is subjected everyday significantly affect the quality. However, there has been no study investigating the effects of different harvest times on quality of saffron so far.

The aim of this study was to determine the alterations in the yield and quality of saffron (Crocus sativus L.) due to different harvest times.

\section{Materials and Methods}

This study was carried out under Harran Plain conditions to determine the diurnal variability in Saffron (Crocus sativus L.). The study material consisted of Iran ecotype of saffron bulbs with 7-10 $\mathrm{cm}$ of circumference. Saffron is an annual plant demonstrating the characteristics of perennial plant under field conditions and has a length of 20-25 cm with purple flowers. Stigmata of plants used as drug and spice consist of three reddish orange parts of 1.5-3.5 cm length. There are 6 petals which are purple violet colored. There are 3 stamens which are yellow. As the plant is a triploid hybrid, it does not create seed (Tanker \& Tanker 1976). This study was carried out in randomized complete block design with three replicates for 2 years during 2006-2007 and 2007-2008 to determine some yield and quality characteristics of saffron (Crocus sativus L.) depending on the harvest time. Flowers blooming during harvest period were harvested at three different times in a day (morning $07.00 \mathrm{~h}$, noon $12.00 \mathrm{~h}$ and evening $17.00 \mathrm{~h}$ ). The bulbs were stored at controlled conditions with $16^{\circ} \mathrm{C}$ and $65 \%$ relative humidity. The field was irrigated once before the planting and when the proper mellowness of soil was reached, deep ploughing was made. Subsequently, the field was ploughed with a cultivator and $50 \mathrm{~kg} \mathrm{da}^{-1} 20.20 .0$ of composed fertilizer was applied as $10 \mathrm{~kg} \mathrm{da}^{-1}$ pure nitrogen and $10 \mathrm{~kg} \mathrm{da}^{-1}$ pure phosphorus, and then the field was cultivated with a rotator. Cultivations were made by hand with 10x10 cm density on 11-13 October 2006 for the initial year and 13-15 October 2007 for the second year. Each lot was arranged in 4 rows of $6 \mathrm{~m}$ length. Certain maintenance processes like irrigation, weeding etc. were made during the trial. Flower harvest was made by hand by discarding $0.5 \mathrm{~m}$ both from the beginning and end of two middle rows at suitable times according to the application on fully bloomed flowers. After stigmata were removed from the flowers, they were dried at $40{ }^{\circ} \mathrm{C}$ for 2 hours. The dried stigmata were kept at room temperature for a day and measurement and weighting procedures were performed. Emergence time, emergence duration, flowering time, flowering duration, flowering period, vegetation time, plant height, number of flower per plant, stigma length, stigma weight, saffron yield, safranal rate, crocin rate, picrocrocin rate, number of small corms, corm yield and marketable corm rate were measured and observed according to the methods reported by Erden (2010). Data were analyzed using the statistical package MSTAT-C.

\section{Results and Discussion}

\subsection{Phenological Observations}

Table 1 shows the phenological observation results determined in the study carried out to determine diurnal variability in Saffron (Crocus sativus L.). When the phenological observation values determined according to diurnal variability in saffron were investigated, blooming dates were determined by years as 5-7 November and 10-12 November and flowering dates were 7-9 November and 13-15 November, respectively. The difference between flowering dates by years could be attributed to late plantation in the second year and ecological factors. In the study, the period between blooming and flowering was determined as 2 and 3 days by years.

$61 \mid \mathrm{P}$ a g e

www.iiste.org 
The flowering period determined for saffron considering diurnal variability changed between 26 and 27 days in the first year and 25 and 26 days in the second year. The results of the study were higher than the findings of Ipek et al. (2009) (9-12 days), while it was quite lower than the findings ( $81-88$ days) reported by Özel \& Erden (2005) for Iran ecotype saffron planted in the middle of October. These differences could be caused by the genotypic variations, different corm size and different ecological conditions.

Table 1. Phenological observations on diurnal variability in saffron

\begin{tabular}{|l|l|l|l|l|l|l|}
\hline Harvest Time & $\begin{array}{l}\text { Sprout } \\
\text { Time }\end{array}$ & $\begin{array}{l}\text { Sprout } \\
\text { Duration } \\
\text { (day) }\end{array}$ & $\begin{array}{l}\text { Flowering } \\
\text { Time }\end{array}$ & $\begin{array}{l}\text { Flowering } \\
\text { Duration } \\
\text { (day) }\end{array}$ & $\begin{array}{l}\text { Flowering } \\
\text { Period } \\
\text { (day) }\end{array}$ & $\begin{array}{l}\text { Vegetation } \\
\text { Duration } \\
\text { (day) }\end{array}$ \\
\hline 2006-2007 & \multicolumn{7}{|l|}{} \\
\hline Morning Harvest & 07.11 .2006 & 26 & 09.11 .2006 & 2 & 26 & 185 \\
\hline Noon Harvest & 05.11 .2006 & 26 & 07.11 .2006 & 2 & 27 & 182 \\
\hline Evening Harvest & 07.11 .2006 & 26 & 09.11 .2006 & 2 & 26 & 185 \\
\hline 2007-2008 & \multicolumn{7}{|l|}{} \\
\hline Morning Harvest & 10.11 .2007 & 29 & 13.11 .2006 & 3 & 26 & 180 \\
\hline Noon Harvest & 12.11 .2007 & 31 & 15.11 .2006 & 3 & 25 & 179 \\
\hline Evening Harvest & 12.11 .2007 & 31 & 15.11 .2006 & 3 & 26 & 180 \\
\hline
\end{tabular}

\subsection{Plant Characteristics}

As shown in Table 2, there was no statistically significant difference between years and applications considering plant height, stigma height, stigma weight, saffron yield, corm number per plant, corm yield and marketable corm rate. The combined values of two years are given in Table 2 and since insignificant results were obtained between the treatments, no further discussion is needed.

Table 2. Mean values of plant heights $(\mathrm{cm})$, stigma lenghts $(\mathrm{cm})$ and stigma weights $(\mathrm{mg})$, saffron yield $\left(\mathrm{g} \mathrm{da}^{-1}\right)$, corm number per plant (corm plant $\left.{ }^{-1}\right)$, corm yield $\left(\mathrm{kg} \mathrm{da}^{-1}\right)$ and marketable corm rate $(\%)$ of saffron for different harvest times

\begin{tabular}{|c|c|c|c|c|c|c|c|}
\hline $\begin{array}{c}\text { Harvest } \\
\text { time }\end{array}$ & \multicolumn{2}{|l|}{} & \multicolumn{3}{|c|}{ Two years combined } & \\
\hline & $\begin{array}{c}\text { Plant } \\
\text { height }\end{array}$ & $\begin{array}{c}\text { Stigma } \\
\text { length }\end{array}$ & $\begin{array}{c}\text { Stigma } \\
\text { weight }\end{array}$ & $\begin{array}{c}\text { Saffron } \\
\text { yield }\end{array}$ & $\begin{array}{c}\text { Corm } \\
\text { number } \\
\text { per plant }\end{array}$ & $\begin{array}{c}\text { Corm } \\
\text { yield }\end{array}$ & $\begin{array}{c}\text { Mark. } \\
\text { corm } \\
\text { rate }\end{array}$ \\
\hline 07.00 & 50.67 & 3.45 & 7.56 & 1958.7 & 4.82 & 3665.33 & 71.35 \\
\hline 12.00 & 50.50 & 3.46 & 7.56 & 1959.1 & 4.78 & 3664.83 & 71.00 \\
\hline 17.00 & 50.60 & 3.46 & 7.56 & 1959.1 & 4.85 & 3664.67 & 71.62 \\
\hline Mean & 50.59 & 3.46 & 7.56 & 1959.0 & 4.82 & 3664.94 & 71.32 \\
\hline LSD (\%5) & N.S. & N.S. & N.S. & N.S. & N.S. & N.S. & N.S. \\
\hline
\end{tabular}

\subsection{Active Ingredient and Quality Determination}

The effects of different harvest periods on safranal rate, crocin rate and picrocrocin rate were found statistically significant, while the years did not have a significant effect. The combined values of two years are given in Table 3.

\subsection{Safranal Rate}

Safranal rate in saffron by diurnal variability changed between $37.60-39.93 \%$ in the first year and 37.57 $39.83 \%$ in the second year, while it changed between $37.58-39.88 \%$ according to the combined values of 
two years. The highest safranal rate was obtained at morning harvest, while the lowest safranal rate was determined at noon harvest in terms of the combined values of two years (Table 3). There was no statistically significant difference between morning and evening harvest applications, and both applications were classified in the same group. Safranal rate was generally found higher at morning and evening harvests than noon harvest. The values obtained were higher than the findings (33.15-62.79\%) reported by Zougagh et al. (2006) considering lower bound and much lower considering the upper bound. This difference could be caused by genotypic and climate factors. It was reported that climate factors and genotype were effective on saffron yield and quality (Özel \& Erden 2005; Gresta et al. 2009). Considering the ISO standard which states that safranal rate has to be equal to or higher than $20 \%$, the values obtained in all applications of the study were higher than this level (Anonymous 2003).

Table 3. Mean safranal rate (\%), crocin rate (\%) and picrocrocin rate $(\%)$ in saffron for different harvest times

\begin{tabular}{|c|c|c|c|}
\hline Harvest time & \multicolumn{3}{|c|}{ Two years combined } \\
\hline & Safranal rate & Crocin rate & Picrocrocin rate \\
\hline 07.00 & $39.88 \mathrm{a}$ & $199.95 \mathrm{a}$ & $89.62 \mathrm{a}$ \\
\hline 12.00 & $37.58 \mathrm{~b}$ & $192.52 \mathrm{~b}$ & $87.00 \mathrm{~b}$ \\
\hline 17.00 & $39.82 \mathrm{a}$ & $199.80 \mathrm{a}$ & $89.53 \mathrm{a}$ \\
\hline Mean & 39.09 & 197.42 & 86.54 \\
\hline LSD (\%5) & 0.08 & 0.21 & 0.13 \\
\hline
\end{tabular}

\subsection{Crocin Rate}

In the study, crocin rates in saffron by diurnal variability changed between $192.53-200.00 \%$ in the first year and $192.50-199.90 \%$ in the second year, while it changed between $192.52-199.95 \%$ considering the combined values of two years. The highest crocin rate was observed at morning harvest, while the lowest crocin rate was determined at noon harvest considering the combined values of two years (Table 3). In addition, there was no statistically significant difference between evening and morning harvests. In general, crocin rate was found lower at noon harvest of saffron flower compared to morning and evening harvests. According to ISO standard, the samples with crocin rates between 150-190\% were classified as second class saffron, while the samples with higher crocin rates were accepted as first class saffron. Accordingly, the saffron in all applications was categorized within the first class saffron group considering crocin rate (Anonymous 2003).

\subsection{Picrocrocin Rate}

The picrocrocin rates in saffron changed between $86.97-89.60 \%$ in the first year and $87.03-89.63 \%$ in the second year by diurnal variability. In addition, the highest picrocrocin rate was observed at morning harvest of saffron flower considering the combined values of two years, while the lowest picrocrocin rate was obtained at noon harvest (Table 3). In general, picrocrocin rate was lower at noon harvest of saffron flower than morning and evening harvests. The values obtained were higher than the findings (50.7$81.1 \%$ ) reported by Gresta et al. (2009). This difference could be caused by different genotypic and climate factors. In fact, genotype (Özel \& Erden 2005) and climate factors (Gresta et al. 2009) were reported to be effective on the yield and quality of saffron. According to the ISO standard, the samples with picrocrocin rate higher than $70 \%$ are classified as first class saffron. The saffron obtained in the study was included in the first class in terms of picrocrocin rate (Anonymous 2003).

\section{Conclusion}

The findings obtained in the study demonstrated that morning and evening harvests of saffron flowers resulted in higher crocin, picrocrocin and safranal rates compared to noon harvest; however, there was no significant difference in terms of yield characteristics. In this regard, it was concluded to be more convenient to harvest saffron flowers early in the morning.

\section{References}

Anonim (2003). ISO ve TSE’nin Safranda Bileşen Analizi İle İlgili Standardı. ISO/TS 3632:2003.

63 | P a g e 
Baytop, T. (1984). Türkiye'de Bitkilerle Tedavi. İstanbul Üni. Ecz. Fak., 40: 360-361. 1984.

Çavuşoğlu, A. \& Erkel, E. İ. (2005). Kocaeli ili koşullarında safran (Crocus sativus L.) yetiştiriciliğinde yetişme yeri ve korm çapı'nın verim ve erkencilik üzerine etkisi. Akdeniz Üniversitesi Ziraat Fakültesi Dergisi, 2005, 18(2), 179-184, 2005.

Demirhan, E. A. (2002). Safran. In: Şifalı Bitkiler- Doğal İlaçlarla Geleneksel Tedaviler. Alfa Yayınlar1: 928, Dizi No.:17, S. 353-355. İstanbul, 2002.

Douglas, M. H. \& Mc Gimpsey, J. A. (1993). The Production of Saffron (Crocus sativus L.) in Central Otago, New Zealand, Proceedings Agronomy Society Conference, (1) 93-97. 1993.

Erden, K. (2010). Harran Ovası Koşullarında Safran (Crocus sativus L.)'da Verim ve Kalite Üzerine Agronomik Çalışmalar. Yayınlanmamış Doktora Tezi: Harran Üniversitesi Fen Bilimleri Enstitüsü, 2010.

Gümüşsuyu, İ. (2003). Dünyanın En Pahalı Baharatı-Safran (Crocus sativus L.), Karabük Valiliği Kültür Yayınları, 2003.

Gresta, F., Avola, G., Lombardo, G. M., Siracusa, L. \& Ruberto, G. (2009). Analysis of flowering, stigmas yield and qualitative traits of saffron (Crocus sativus L.) as affected by environmental conditions. Scientia Horticulturae 119 (2009) 320-324, 2009.

İpek, A., Arslan, N. \& Sarıhan, E. O. (2009). Farklı Dikim Derinliklerinin ve Soğan Boylarının Safranın (Crocus sativus L.) Verim ve Verim Kriterlerine Etkisi. Tarım Bilimleri Dergisi, 15(1) 38-46, 2009.

Koç, H. (2002). Safran. In: Bitkilerle Sağlıklı Yaşama. T. C. Kültür Bakanlığı, Kültür Eserleri Dizisi/373, S.309-310. Ankara, 2002.

Leung, A. Y. (1980). Encyclopedia of Common Natural Ingredients in Food, Drugs and Cosmetics, Wiley, New York, USA.

Molina, R. V., Valero, M., Navarro, Y., Garcia-Luis, A. \& Guardiola, J. L. (2005). Temperature effects on flower formation in saffron (Crocus sativus L.). Scientia Horticulturae 103 (2005) 361-379, 2005.

Özel, A. \& Erden, K. (2005). Harran Ovası Koşullarında Yerli ve İran Safran (Crocus sativus L.)'ının Verim ve Bazı Bitkisel Özelliklerinin Belirlenmesi. GAP IV. Tarım Kongresi, S. 793-798. 21-23 Eylül Şanlıurfa, 2005.

Özel, A., Erden, K. (2008). Harran Ovası Koşullarında Safran (Crocus sativus L.)'da Uygun Yumru İriliğinin Belirlenmesi. Kesin Sonuç Raporu. HÜBAK 528 No'lu Proje, 2008.

Şekercioğlu, N. (1999). Şifalı Bitkiler Ansiklopedisi. Bilim Teknik Yayınevi, İstanbul, 1999.

Tanker, M. \& Tanker, N. (1976). "Farmakognozi” Cilt 2, İstanbul, 1976.

Zougagh M., Rios, A. \& Valcarcel M. (2006). Determination of total safranal by in situ acid hydrolysis in supercritical fluid media: Application to the quality control of commercial saffron. Analytica Chimica Acta 578: 117-121, 2006. 